\title{
TRANSFORMAÇÕES OCORRIDAS NO PARQUE DA ESCOLA SUPERIOR DE AGRICULTURA "LUIZ DE QUEIROZ" - (ESALQ- USP) EM PIRACICABA - SP, AO LONGO DOS ANOS
}
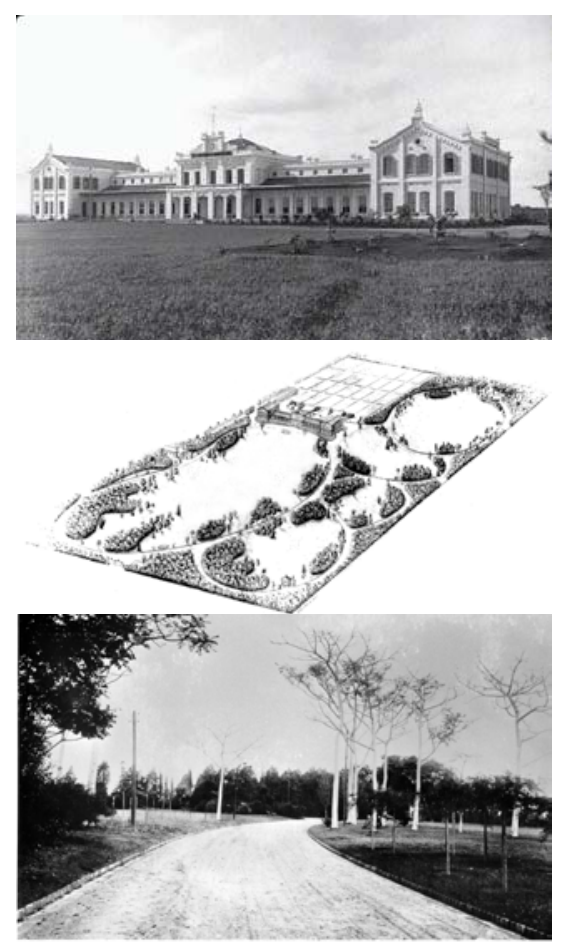

Henrique Sundfeld Barbin

Engenheiro agrônomo MS, doutorando do Departamento de Produção Vegetal da ESALQ/USP.

\section{Valdemar Antonio \\ Demétrio}

Engenheiro agrônomo,

Prof. Dr. do Departamento de Engenharia Rural da ESALQ/USP. 


\section{RESUMO}

No presente estudo, foram utilizados fotografias aéreas verticais e levantamentos florísticos de épocas distintas, para acompanhar as transformações ocorridas nos maciços vegetais do Parque da Escola Superior de Agricultura "Luiz de Queiroz" (ESALQ), da Universidade de São Paulo (USP), em Piracicaba. O parque, de $150.000 \mathrm{~m}^{2}$, construído em estilo inglês de paisagismo, foi implantado ao redor de 1907 e teve crescimento descontrolado e demasiado das áreas de seus maciços arbóreos, comprovado pela análise de fotografias aéreas verticais a partir do ano de 1945, que mostram o aumento em área dos referidos maciços propostos no projeto original. Nos projetos paisagísticos, considera-se a média de 20 anos, para que a cobertura florística atinja os limites representados geograficamente. Usando-se o software IDRISI, fotografias aéreas verticais dos anos de 1945, 1962, 1969, 1973, 1993 e 1995 e o projeto original do parque, calculou-se a área de cada um dos 24 maciços vegetais presentes no parque, nos diferentes anos, e estas foram confrontadas. No período de 1945 a 1995, o incremento arbóreo foi de $36.655 \mathrm{~m}^{2}$, praticamente dobrando a área total de cobertura.

No projeto original do parque da ESALQ, foram planejadas dez linhas de visada. Em 1995, seis dessas linhas estavam obstruídas. Destas, quatro podem ser desobstruídas, por meio de práticas simples de manejo, e as outras duas ficam impossibilitadas de desobstrução.

Quanto ao estudo dos levantamentos florísticos dos maciços arbóreos, os mesmos revelam que, em 1965, o parque era formado por 444 indivíduos arbóreos, sendo este valor aumentado para 2.904, em 1991. Fatos apresentados indicam a necessidade de um manejo adequado urgente dos maciços vegetais do parque da ESALQ, para evitar maior descaracterização do mesmo.

\section{ABSTRACT}

In the present study, vertical aerial photographs and floristic surveys from different times were used to assess the transformation on plant masses of the Park of the Escola Superior de Agricultura "Luiz de Queiroz " (ESALQ), Universidade of São Paulo (USP), in Piracicaba - SP - Brazil. The park, comprised of $150.000 \mathrm{~m}^{2}$, was built in the english landscape style, near 1907, and has had too much uncontrolled growth of arboreal/ shrubby masses ever since, as determined by the analysis of vertical aerial photographs taken in 1945. In the large seal landscape projects it takes approximately twenty years for the plant mass to reach its peak. The area of the 24 existent masses in the Park was calculated at different years and compared, using software IDRISI, vertical aerial photographs from 1945, 1962, 1969, 1973, 1993, and 1995, as well as the original project of the Park. From 1945 to 1995, the arboreal increment was of $36.655 \mathrm{~m}^{2}$, practically doubling the total area of arboreal covering.

In the original project of the ESALQ's Park, ten lines of view were planned. In 1995, six of those lines were obstructed. Four of them can be cleared through simple management practices. Unfortunately, the others are no longer liable to desobstruction. The study of the floristic surveys of the arboreal/shrubby masses (masses number 1 to 22), carried out in the park in the years of 1965 and 1991, were typed in the software Access. The floristic survey of 1965 shows that the park was 444 made up of arboreal/shrubby individuals, which increased to 2.904 in the floristic survey in 1991. The presented facts indicate the need of an urgent management of the masses of the ESALQ's Park, to avoid further uncharacterization. 


\section{TRANSFORMAÇÕES OCORRIDAS NO PARQUE DA ESCOLA SUPERIOR DE AGRICULTURA "LUIZ DE QUEIROZ" - (ESALQ-USP) EM PIRACICABA - SP, AO LONGO DOS ANOS}

\section{Introdução}

O Parque da Escola Superior de Agricultura "Luiz de Queiroz" é o único parque em estilo inglês de paisagismo existente no Brasil, cujas características foram parcialmente preservadas. Criado ao redor de 1907, compreende aproximadamente 15 ha, sendo, na cidade de Piracicaba - SP, onde está instalado, o segundo maior em dimensões e o mais freqüentado dentre os cinco parques existentes, que são: Parque do Zoológico (com 4,8 ha), Parque da Zona Leste (3,26 ha), Parque da Rua do Porto (25,2 ha) e o Parque do Mirante (com 1,64 ha). Estes citados parques pertencem ao estilo misto de paisagismo, que proporciona liberdade total ao paisagista, de misturar vários estilos. O parque da ESALQ é classificado, segundo Montenegro (1983), como sendo parque de preservação e setorial, pois tem a finalidade de conservar valores naturais que mereçam ser perpetuados e estudados, além de ser grande área destinada à recreação de toda a população municipal e regional, que o utiliza, principalmente, nos fins de semana e nas férias.

Formado por uma gama de espécies vegetais, nativas e exóticas, é muito utilizado pelos cursos ministrados na referida Escola, para estudos, pesquisas e atividades didáticas, sendo de grande valor histórico e científico, contribuindo na amenização do microclima regional.

parque é formado por canteiros de tamanhos e formas variadas, separados por ruas e compostos por cinco gramados e 24 maciços arbóreos, algumas construções, além de um canteiro que circunda o prédio da administração (Prédio Central). Ao longo dos tempos, os referidos maciços cresceram desordenada e demasiadamente, do ponto de vista de projeto paisagístico, vindo a modificar algumas das importantes características do estilo inglês de paisagismo, propostas pelo arquiteto paisagista, idealizador do projeto do parque, o belga Arsenio Puttemans. Do ponto de vista silvicultural, nota-se um grande domínio, em número, de algumas espécies vegetais sobre outras, dentro dos maciços arbóreos.

presente trabalho tem como objetivos estudar, no decorrer dos anos, as transformações dos traçados ocorridos nos maciços vegetais projetados, utilizando-se de recursos computacionais e fotografias aéreas, bem como confrontar levantamentos florísticos dos maciços do parque, elaborados em épocas diferentes. 


\section{O Parque da ESALQ}

O Parque da Escola Superior de Agricultura "Luiz de Queiroz" da Universidade de São Paulo é a principal área verde do município de Piracicaba - SP, apresentando uma coleção de espécies botânicas, regionais e exóticas, além de possuir grande valor científico e histórico. $\bigcirc$ parque, de grande valia para realização de estudos e atividades didáticas, é muito procurado pela população (CAMPOS, 1991).

Segundo Lima (1987), o parque foi idealizado pelo arquiteto e paisagista belga Arsenio Puttemans, sendo que o projeto original teve início de implantação por volta de 1905, com o auxílio de Luiz Teixeira Mendes, professor de fruticultura e silvicultura da Escola na época, e inaugurado em meados de 1907 (Figuras 1 e 2). Pode-se observar, na Figura 2, outros maciços e, aos fundos, o Prédio Central e o galpão, no qual no lugar foram construídos dois lagos.

Cabe lembrar que não se sabe da existência de lista ou sugestão feita pelo idealizador do projeto paisagístico do parque, referente às espécies vegetais a serem utilizadas no mesmo, ficando, esta tarefa, para os responsáveis pela implantação. Também não se sabe se estes últimos fizeram catalogação das plantas que foram colocadas na área.

citado projeto foi quase totalmente implantado, faltando apenas a construção de um coreto, que deveria ser construído na parte frontal-direita do parque, conforme se pode observar na perspectiva do projeto elaborada por seu autor (Figura 3).

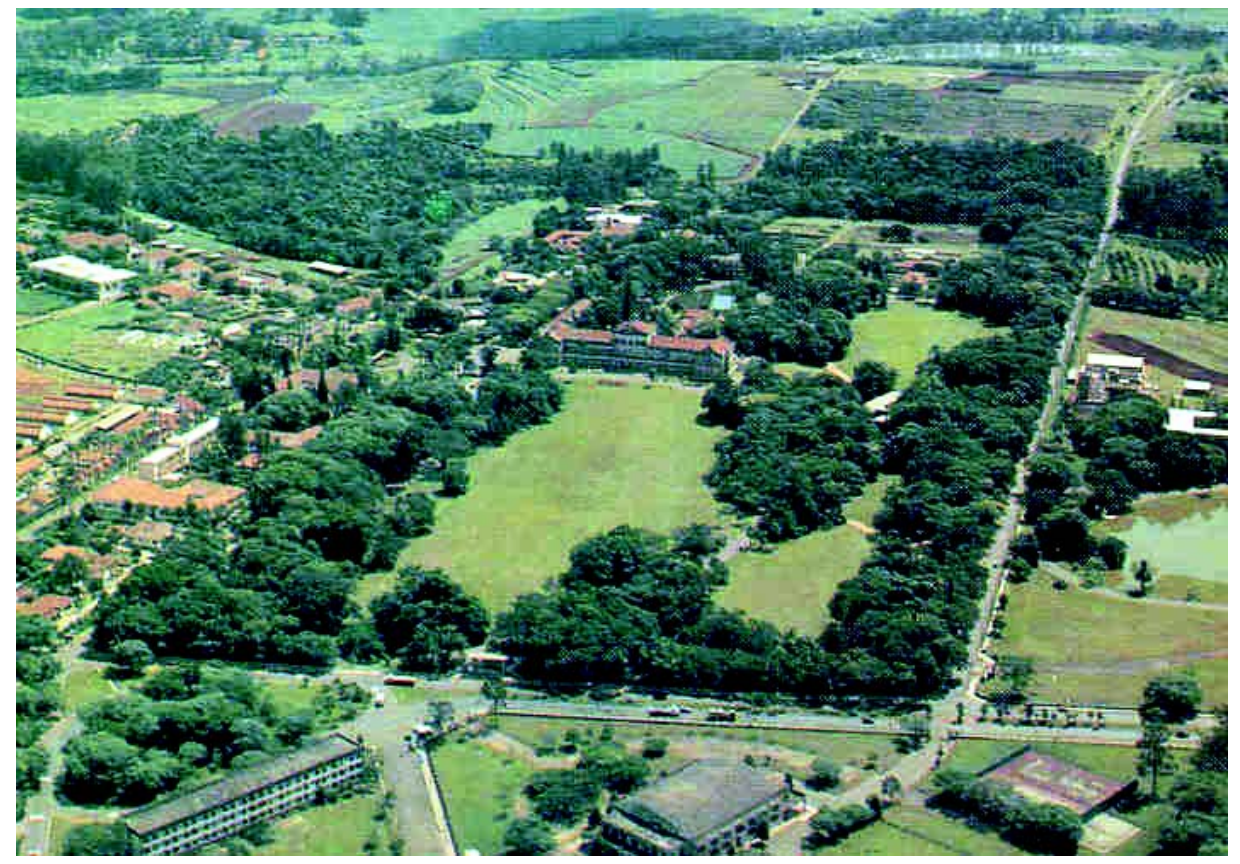

Figura 1 -

Fotografia mostrando o parque nos dias atuais Fonte: Arquivo ESALQ 
Figura 2

Fotografia

ilustrando um maciço logo após sua implantação e

o Prédio Central

Fonte: Arquivo ESALQ
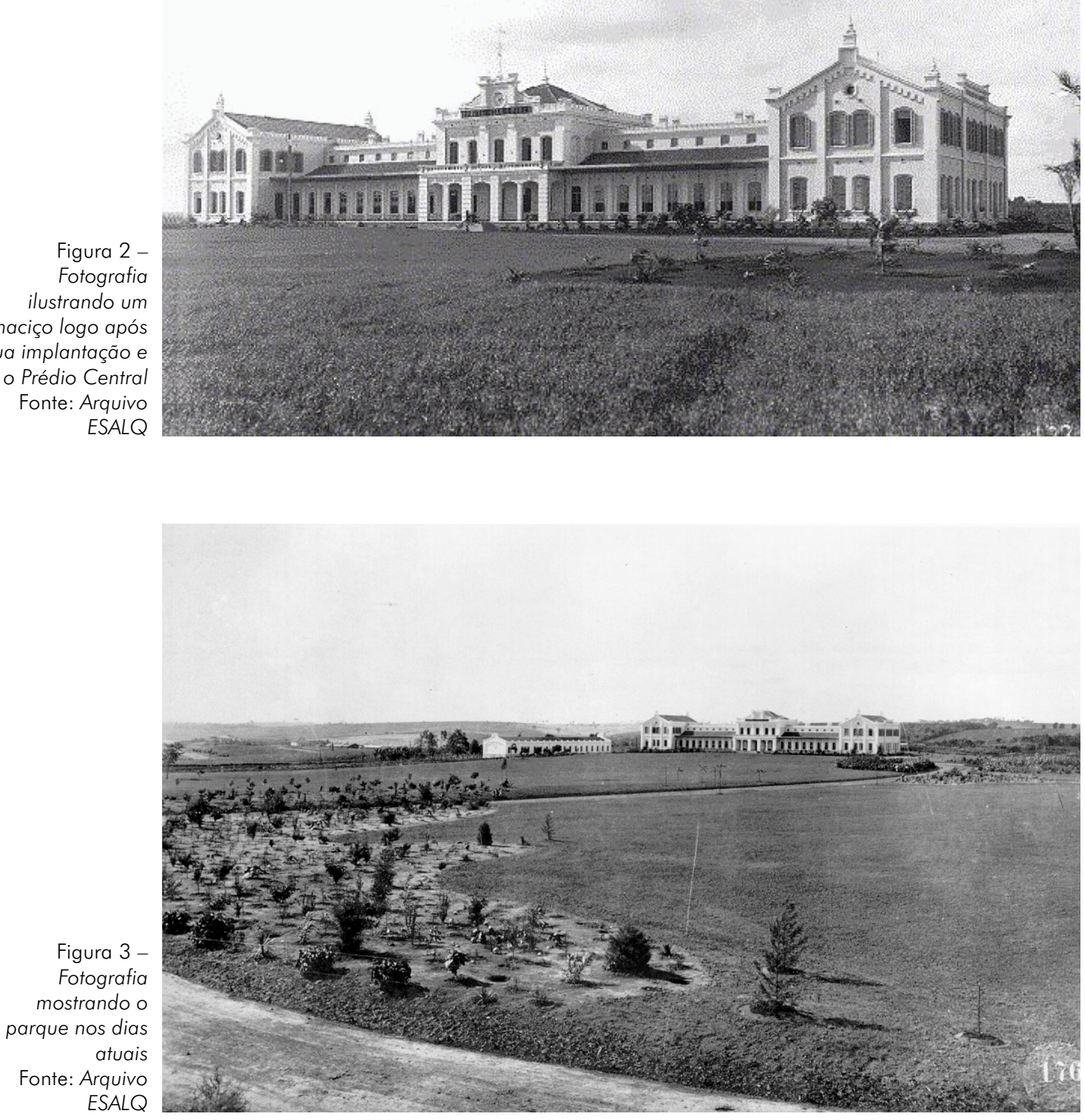

Entre os anos de 1922 e 1959, iniciou-se uma fase de expansão e manutenção do projeto original, sob responsabilidade do professor Philippe Westin Cabral de Vasconcellos, que idealizou os canteiros ao redor dos pavilhões de Química (1930), Horticultura (1946) e Engenharia (1947 - 1948), orientando a introdução de espécies tanto nativas como exóticas (Figura 4). Essa dedicação foi reconhecida e, em maio de 1986, o parque passou a ser denominado oficialmente de "Parque Philippe Westin Cabral de Vasconcellos". 


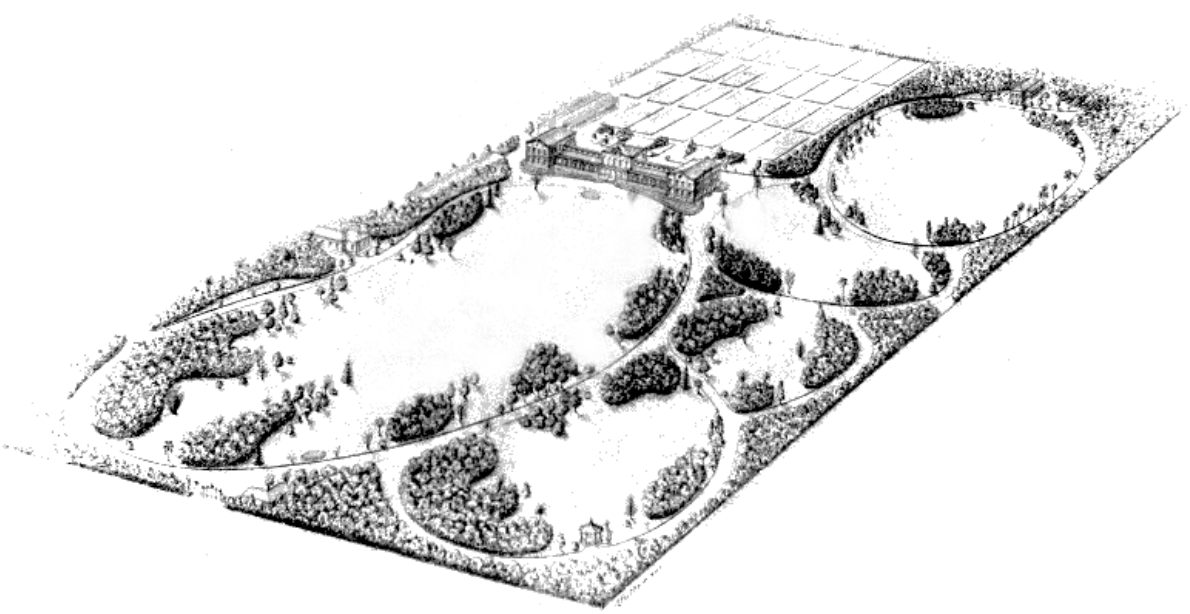

Figura 4 Desenho do projeto original do parque da ESALQ visto em perspectiva Fonte: Arquivo ESALQ

Ocorreram algumas outras modificações, como a construção de dois lagos, na parte esquerda do parque, em 1935, projetados pelo professor Philippe Westin Cabral de Vasconcellos, responsável pelo parque na época. No local da implantação havia anteriormente um galpão destinado à ginástica e depois ocupado pelo Laboratório de Química. Esses dois lagos, mais o lago defronte ao Pavilhão de Engenharia (1948) e o defronte ao Prédio da Horticultura (1946), foram construídos para servirem de reservatórios de água, na prevenção de incêndios e irrigação de diversas culturas. Tempos depois, por volta de 1966, foi construído um prédio destinado a abrigar a Biblioteca da Escola, na qual, hoje, funciona a Seção de Alunos, que veio descaracterizar o projeto original, ocupando local em que passavam duas linhas de visada, além de ter a fachada de tijolo à vista e concreto, totalmente diferente do material utilizado no Prédio Central e de outras construções existentes no parque. Houve a construção de um portal, na entrada principal do parque, e, ainda, a pavimentação de parte de suas ruas e conseqüente impermeabilização, fato este que, apesar de não estar nas citações de Bellair; Bellair (1939), contraria os princípios agronômicos, no tocante à infiltração de águas pluviais. Cabe lembrar que pelas observações em outros parques, não importando o estilo dos mesmos, a prática da impermeabilização dos caminhos restringe-se a locais necessários.

Como destaque de alta relevância para a comunidade, no parque, repousam os corpos de Luiz Vicente de Souza Queiroz e de sua esposa, a sra. Ermelinda Ottoni de Souza Queiroz. O canteiro de flores que abriga as lápides encontra-se defronte ao Prédio Central, respeitando o estilo inglês.

Segundo Vasconcellos (1976), em meados de 1941, foi implantado, no gramado central do parque, próximo ao Prédio Central, um marco geodésico, doado pelo governo do estado, para auxílio nos estudos de astronomia e orientação dos mapas topográficos.

Quando Luiz Vicente de Souza Queiroz doou as terras para que fosse construída uma escola agrícola, o mesmo, segundo relatos colhidos, pediu 
para que os solos mais férteis ficassem para a lavoura, enquanto a área de solo mais pobre, para o jardim. Portanto, o local em que se construiv o parque tinha condições precárias de solo, tendo sido necessário um árduo trabalho de troca de solo (Figura 5), realizado por vagonetes em trilhos puxados por animais. Mesmo com essa troca de solo, as plantas demoravam muito tempo para crescer, tendo sido acelerado o processo, a partir do momento em que o material vegetal existente embaixo dos maciços, decorrente da queda de folhas, ramos, frutos etc., deixou de ser recolhido, enriquecendo, assim, o solo.

Figura 5 - Planta baixa ilustrando a área total do parque. No destaque se pode observar a área projetada originalmente Fonte: Barbin

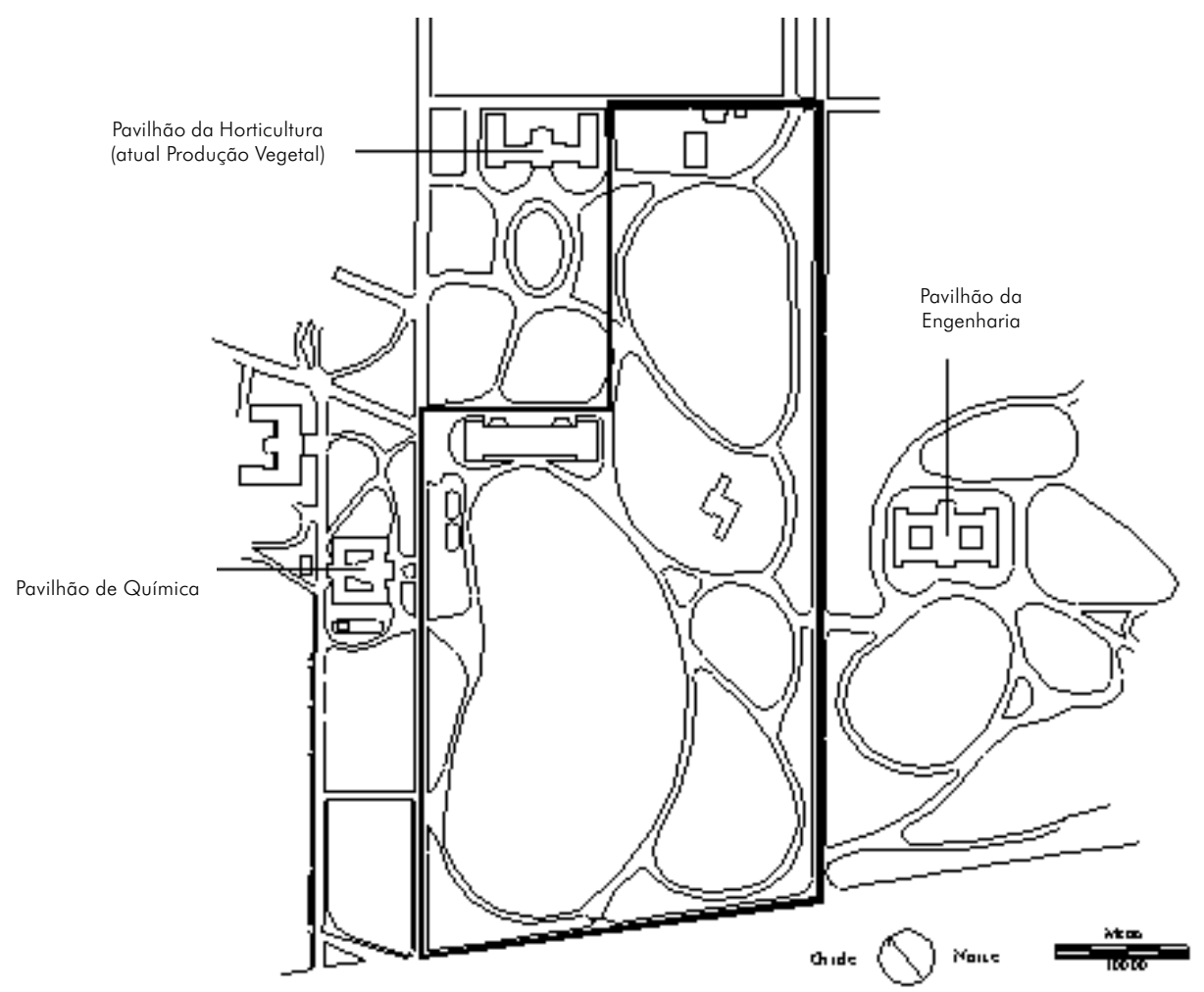

Outro fato interessante é que como o solo local é muito raso, tendo folhelhos de formação Corumbataí, a alguns centímetros de profundidade, nos locais que seriam implantados os maciços, a deposição de solo foi maior, formando verdadeiros murundus, para que as raízes das árvores tivessem mais espaço vertical para se desenvolverem. Este fato é citado na revisão bibliográfica sobre o estilo inglês de paisagismo.

Lima (1987) salienta a importância da conservação do Parque da ESALQ como patrimônio histórico, já que das poucas obras realizadas no Brasil por Arsenio Puttemans, ou seja, o projeto do Jardim do Ipiranga, o da Praça da República e da Várzea do Braz, em São Paulo, bem como a Praça de São Bento, em Niterói (Figura 6), o Parque da ESALQ é hoje a única obra que permanece praticamente inalterada. 


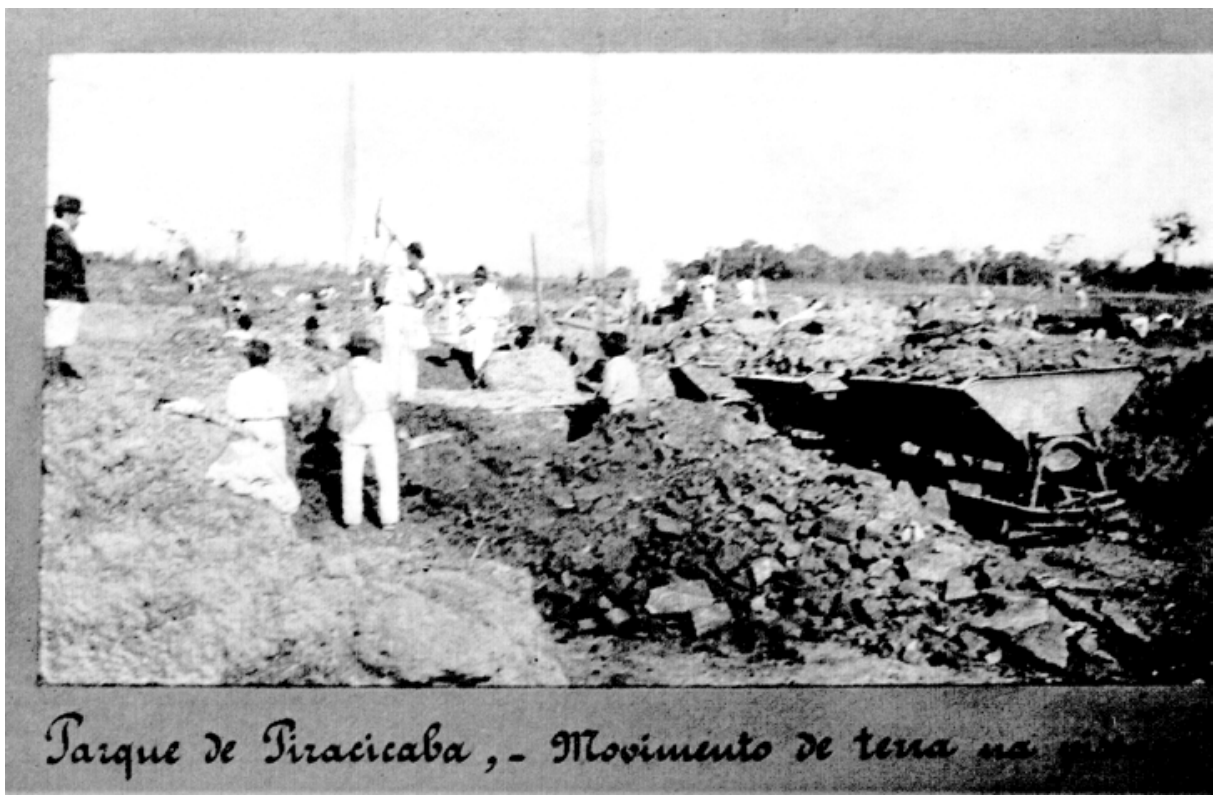

Figura 6 -

Fotografia ilustrando a troca de solo na implantação do parque por volta de 1906 Fonte: Arquivo ESALQ

\section{Material Utilizado}

A área trabalhada é o Parque da Escola Superior de Agricultura "Luiz de Queiroz" da Universidade de São Paulo, campus de Piracicaba - SP, de aproximadamente 15 hectares, projetada pelo arquiteto-paisagista Arsenio Puttemans, e apresenta o desenho original. É formada por canteiros de tamanhos e formas variadas, separados por ruas e compostos por cinco gramados e 24 maciços arbóreos, sendo o de número 24 dividido em sete minimaciços ( $a, b, c, d, e, f$ e g). Apresenta ainda algumas construções, tais como: os prédios da Administração (Prédio Central), da Seção de Graduação, do Serviço Odontológico e o da Microscopia Eletrônica, além de um canteiro que circunda o Prédio da Administração (Figura 7).

O terreno sobre o qual foi implantado o parque é um aterro, suavemente ondulado (RANZANI, 1965) e, portanto, não pode ser enquadrado em nenhuma classificação de solo (Figura 8).

Para a realização deste trabalho foram utilizados os seguintes materiais: microcomputador PC 486 e Pentium II; Scanner Scanjet 4c; software IDRISI para Windows, software Adobe Photoshop 5,0 para Windows, software Autocad 14 para Windows, distanciômetro eletrônico, levantamentos florísticos realizados em 1965 e 1991, software Access 2.0 para Windows, software Excel 5.0, para Windows, planta baixa do projeto original do parque (Figura 9) e fotografias aéreas verticais da região, de épocas diferentes.

Procurou-se adquirir o máximo e na maior amplitude possível, em anos, de fotografias aéreas verticais da região de Piracicaba - SP, para se ter estudo mais completo possível da área em questão. As fotografias aéreas verticais 
Figura 7 - Projeto da praça São Bento, em Niterói Fonte: Arquivo ESALQ

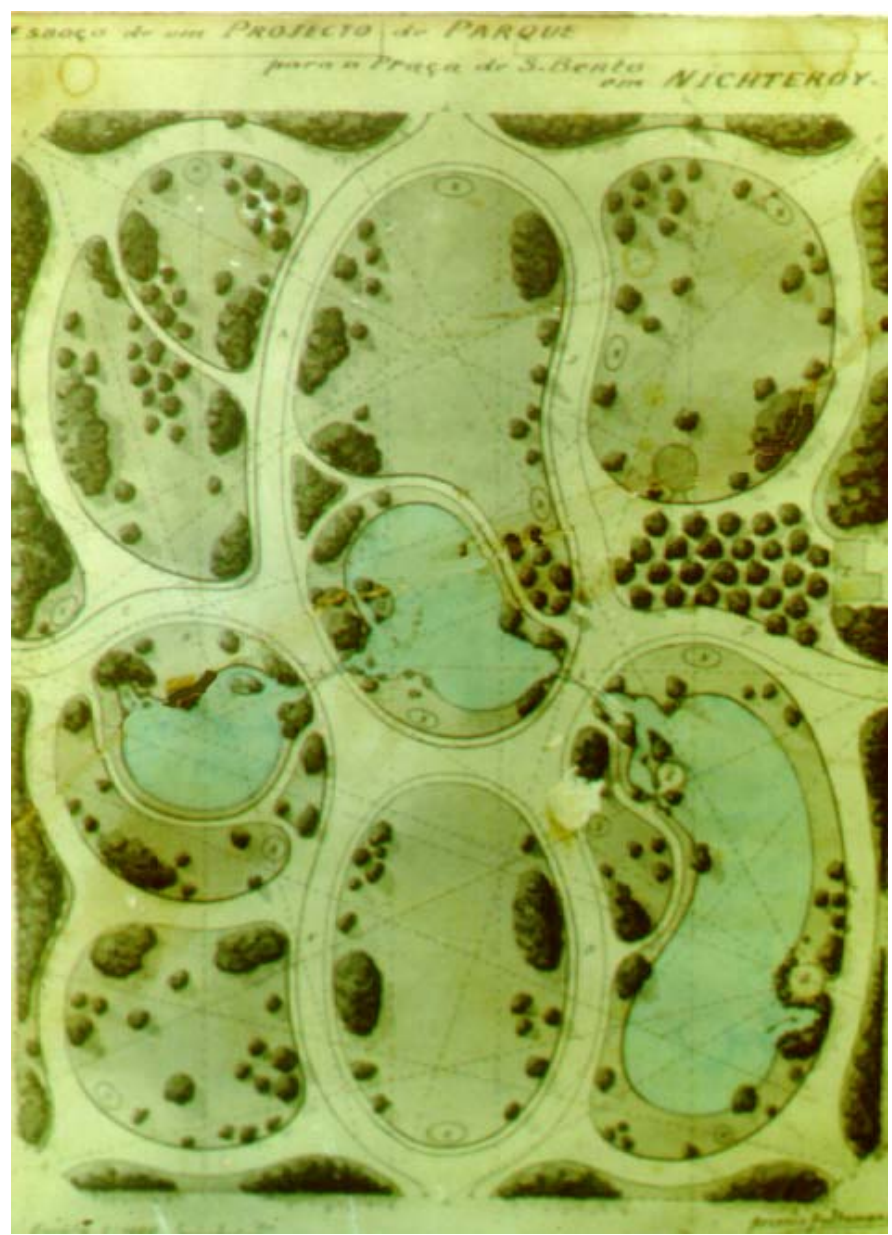

Figura 8: Mapa com os prédios e os nomes das ruas que delimitam o parque e os números dos maciços arbóreos estudados Fonte: Barbin

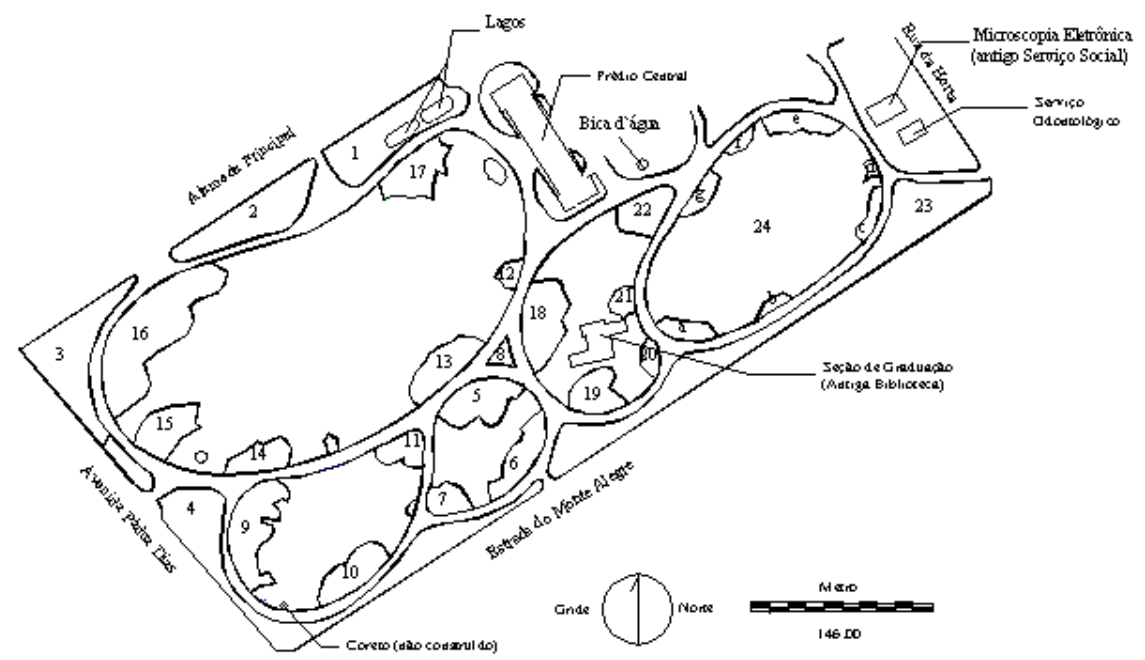

Paisagem Ambiente: ensaios - n. 17 - São Paulo - p. 69 - 89 - 2003 


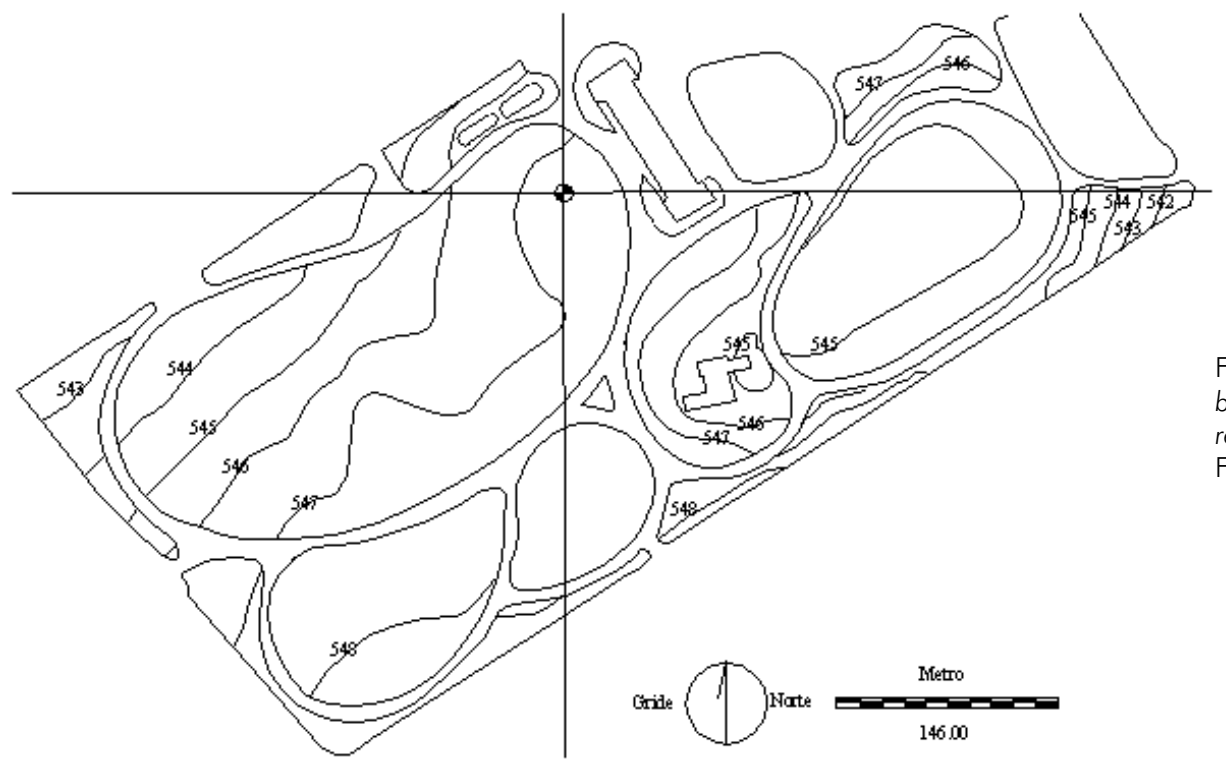

Figura 9 - Planta baixa mostrando o relevo do parque Fonte: Barbin

adquiridas são as seguintes: 1945 - na escala de $1: 10000 ; 1962$ - na escala de 1:25000; 1969 - na escala de 1:8000; 1973 - na escala de 1:8000; 1993 - na escala de 1:5000; 1995 - na escala de 1:25000.

\section{Metodologia Implantada}

As fotografias aéreas das épocas mencionadas foram rasterizadas utilizando o scanner, procurando-se obter maior definição possível nas imagens, embora, como enfatiza Spurr (1948), o fator sombra se apresentou em algumas fotografias, com seu aspecto negativo de obscurecer alguns detalhes. A base para se determinar o número de pontos por polegada (dots per inch - DPIs) para cada escala foram as imagens em escala 1:25000, por apresentarem menor resolução. Testaram-se várias alternativas na rasterização das fotografias e a imagem de maior definição encontrada, ou seja, a visualmente mais bem definida pelo digitalizador, que foi extrapolada para a digitalização das fotografias de diferentes escalas.

As imagens foram importadas pelo software IDRISI, os maciços foram digitalizados para obtenção analítica das áreas. Cabe lembrar que na fotografia aérea vertical as copas das árvores são projetadas no solo e, portanto, a área de um determinado maciço equivale à área de projeção da copa e não do limite real do maciço. As dúvidas entre áreas sombreadas e áreas de interesse, representadas pelos dosséis dos maciços, foram sanadas pelo uso de pares estereoscópicos. A área de cada um dos 24 maciços foi calculada. $\bigcirc$ referido software permite criar layers mostrando imagens contendo os maciços, de cada data estipulada. Estes foram sobrepostos, a fim de facilitar a observação das transformações ocorridas nos maciços. 
Quanto à parte botânica do parque, estudaram-se os levantamentos florísticos, realizados em 1965 e 1991 e confronto das espécies presentes nos mesmos. Pela não-existência da planta baixa de localização física das espécies arbóreas e arbustivas por maciço, no levantamento florístico e fitossociológico de 1965, a análise teve de ser feita, considerando-se o parque como um todo, não podendo, portanto, confrontar maciço a maciço, nas diferentes datas, o que permitiria levantar as mudanças ocorridas em cada um deles, fato este que enriqueceria ainda mais este trabalho.

Os nomes das espécies encontradas no levantamento florístico de 1965 foram revisados e atualizados quando necessário, por meio de consulta a material bibliográfico.

Os dados obtidos nos citados levantamentos florísticos, após revisão e atualização, foram digitados no software Access 2.0, no qual se montou, para cada levantamento, uma tabela. $O$ confronto de espécies presentes no parque, nas épocas estudadas, foi realizado pela ferramenta consulta, do software Access 2.0, na qual também foram montadas tabelas.

Para o estudo das linhas de visada, propostas no projeto original, realizou-se com auxílio do distanciômetro eletrônico, levantamento em campo, em que se delimitaram os perímetros de todos os maciços arbóreos, tomando-se como base os limites maciço-gramado, maciço-guia e gramado-guia. Em locais cujas copas das árvores se curvavam para baixo, ficando a altura inferior aos olhos do observador, tomou-se como base, para definir o limite gramadobosque, a projeção da copa no solo. Esta metodologia foi adotada para se ter o real ângulo de visualização do observador, pois, estando a copa da árvore abaixo da citada altura, a linha de visualização é interrompida. Estes dados foram exportados para o software Autocad 14, no qual se montou a planta baixa do parque.

As linhas de visada, característica importante do estilo inglês de paisagismo, foram traçadas sobre imagem da referida planta baixa do parque, formando um layer, por meio de observações visuais feitas no projeto original. Pôde-se, por esse mapa, analisar quais visadas estão interrompidas, quais as ainda visíveis e saber o que está interrompendo. Para isto, realizou-se levantamento florístico, in loco, nos maciços que estão impedindo a visualização, para saber quais e quantas árvores estão ali presentes.

Sabe-se, de antemão, que o prédio construído em 1966, em um dos gramados do parque, para servir de biblioteca da Escola (hoje Seção de Graduação e Pós-Graduação), obstruiu duas linhas de visadas imaginárias, conforme se pode observar na Figura 10.

A fim de verificar se a posição do maciço, em relação ao caminhamento solar, influenciou no crescimento dos maciços, realizou-se estudo utilizando-se do IDRISI e confrontando os maciços que apresentam a face voltada para o leste e, portanto, ficam expostos à insolação do período matutino, e os com a face 


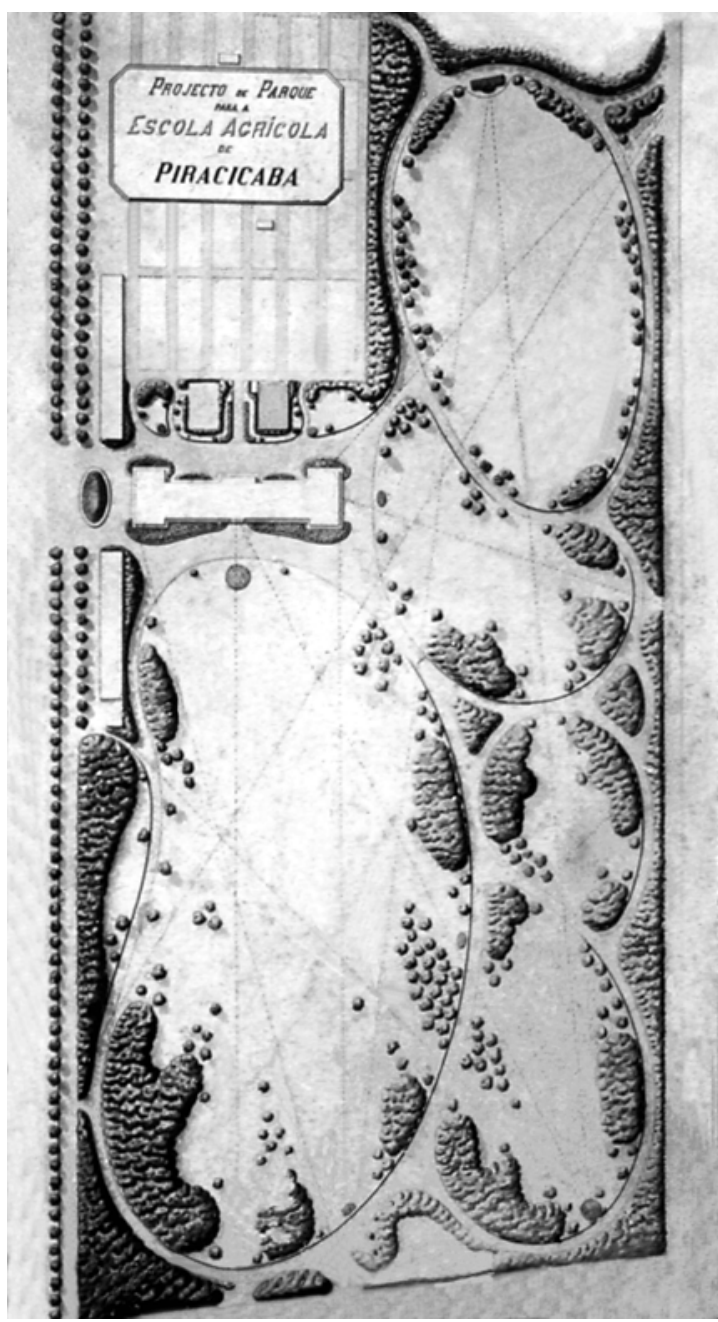

Figura 10 - Projeto original do Parque da ESALQ

Fonte: Arquivo ESALQ

voltada para o oeste, expondo-se, portanto, à insolação do período vespertino. Foram confrontados também, seguindo a mesma metodologia, os maciços arbóreos com face leste e oeste, os quais recebem insolação direta, seja no período matutino ou vespertino, com os de face sul e norte e que, portanto, não recebem insolação direta em nenhum momento do dia.

\section{Resultados Obtidos}

Para facilitar a discussão, os resultados deste trabalho foram divididos em dois itens: Descaracterização da Área de Cobertura Arbórea, que discute as transformações ocorridas nos maciços arbóreos do parque, no tocante ao grande crescimento em área dos maciços e sua composição florística; Descaracterização das Linhas de Visadas Imaginárias, que discute a obstrução de linhas de visada idealizadas em seu projeto original. 


\section{Descaracterização da Área de Cobertura Arbórea}

\section{Área dos maciços arbóreos}

Por meio de medições realizadas nas imagens corrigidas, usando-se do software IDRISI, pôde-se observar que os maciços cresceram, em área, de forma desordenada e demasiada (Tabela 1), causando uma grande descaracterização no proposto do projeto original (Figura 11). Pode-se observar, no projeto original, as ruas totalmente descobertas, enquanto nas imagens as copas das árvores cresceram, chegando, em vários locais, a encobrir totalmente as ruas, não seguindo os preceitos do estilo inglês, apregoados por Bellair \& Bellair (1939), que pode ser fruto de uma adequação do estilo ao Brasil devido às altas temperaturas, mas não se sabe nada sobre o assunto.

Nota-se ainda em alguns locais, por falta de manutenção adequada, a formação de maciços que, no planejado pelo paisagista, era ter-se algumas árvores isoladas. Este fato é evidenciado no maciço de número 14, como podemos observar na Figura 12.

Analisando-se a tabela, pode-se observar que todos os maciços arbóreos cresceram em área, tomando-se por base os anos 1945 e 1995, que é a maior amplitude das medições. $\bigcirc$ maciço 8 teve comportamento inexplicável, estando em $1945 \mathrm{com} 337 \mathrm{~m}^{2}$, passando a $1.180 \mathrm{~m}^{2}$, em 1973, e voltando a $311 \mathrm{~m}^{2}$, em 1995, sendo, portanto, o único a decrescer.

Figura $11-$ Mapa contendo os maciços arbóreo/ arbustivos, as linhas de visada imaginárias obstruídas (linhas vermelhas), as desobstruídas (linhas azuis) e os prédios Fonte: Barbin

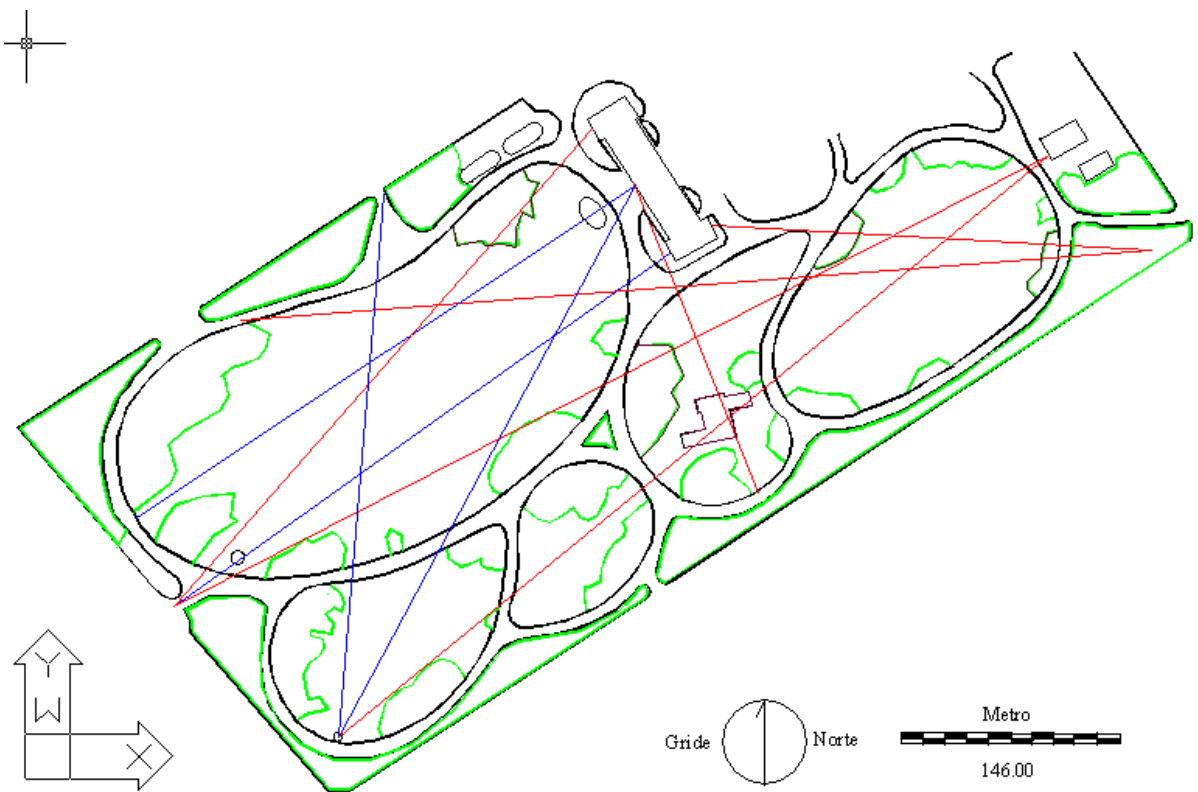


Tabela 1 - Área de cada maciço arbóreo $\left(\mathrm{em} \mathrm{m}^{2}\right)$, nos anos investigados e no projeto original, calculada por meio do software IDRISI

RESULTADO DA MEDIÇÃO REALIZADA EM:

\begin{tabular}{|c|c|c|c|c|c|c|c|}
\hline $\begin{array}{l}\text { Maciço } \\
\text { número }\end{array}$ & $\begin{array}{l}\text { Projeto } \\
\text { original } \\
(1927)^{*}\end{array}$ & 1945 & 1962 & 1969 & 1973 & 1993 & 1995 \\
\hline 1 & - & 1.114 & 1.103 & 1.137 & 1.792 & 1.579 & 1.672 \\
\hline 2 & 2.329 & 2.537 & 3.177 & 3.521 & 3.912 & 4.676 & 4.493 \\
\hline 3 & 2.624 & 2.992 & 2.470 & 3.617 & 3.776 & 4.157 & 3.920 \\
\hline 4 & 4.434 & 3.187 & 4.703 & 5.488 & 4.868 & 7.996 & 8.395 \\
\hline 5 & 896 & 1.555 & 1.220 & 1.695 & 1.747 & 2.799 & 2.391 \\
\hline 6 & 321 & 514 & 709 & 430 & 528 & 1.098 & 915 \\
\hline 7 & 932 & 1.152 & 1.570 & 1.928 & 1.748 & 2.764 & 2.679 \\
\hline 8 & 256 & 337 & 750 & 752 & 1.180 & 310 & 311 \\
\hline 9 & 1.941 & 1.424 & 1.558 & 1.883 & 1.999 & 2.603 & 2.650 \\
\hline 10 & 998 & 1.335 & 1.277 & 1.466 & 1.579 & 2.374 & 2.648 \\
\hline 11 & 504 & 835 & 880 & 1.033 & 720 & 1.186 & 1.237 \\
\hline 12 & 134 & 312 & 381 & 574 & 522 & 761 & 664 \\
\hline 13 & 1.181 & 1.792 & 1.382 & 2.030 & 2.339 & 3.110 & 3.104 \\
\hline 14 & 997 & 922 & 975 & 1.118 & 1.175 & 1.894 & 1.931 \\
\hline 15 & 689 & 1.114 & 1.170 & 1.629 & 1.120 & 1.899 & 2.115 \\
\hline 16 & 3.766 & 4.129 & 4.126 & 6.601 & 6.006 & 7.110 & 7.975 \\
\hline 17 & 534 & 1.431 & 1.546 & 2.775 & 2.525 & 3.091 & 3.397 \\
\hline 18 & 1.009 & 718 & 1.357 & 2.366 & 2.277 & 3.038 & 3.185 \\
\hline 19 & 660 & 1.380 & 1.637 & 1.754 & 1.771 & 2.228 & 2.543 \\
\hline 20 & 443 & 549 & 582 & 633 & 570 & 1.028 & 1.298 \\
\hline 21 & 54 & 294 & 334 & 492 & 468 & 528 & 536 \\
\hline 22 & 93 & 479 & 487 & 759 & 614 & 781 & 918 \\
\hline 23 & 2.210 & 7.276 & 8.313 & 9.976 & 10.065 & 13.127 & 13.020 \\
\hline $24^{* *}$ & 1.320 & 3.598 & 3.410 & 4.557 & 3.828 & 6.323 & 5.227 \\
\hline Total & 28.641 & 40.576 & 45.114 & 58.211 & 57.127 & 76.456 & 77.221 \\
\hline
\end{tabular}

* O projeto original é datado de 1907, mas conforme já comentado, o projeto reflete a realidade após 20 anos.

** Soma dos minimaciços $a, b, c, d, e, f$ e $g$. 


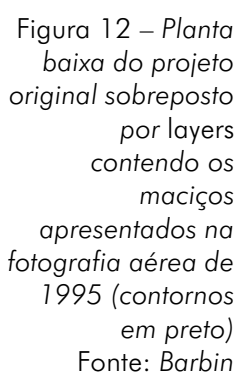

Figura 12 - Planta baixa do projeto por layers contendo os maciços ografia aérea de em preto)

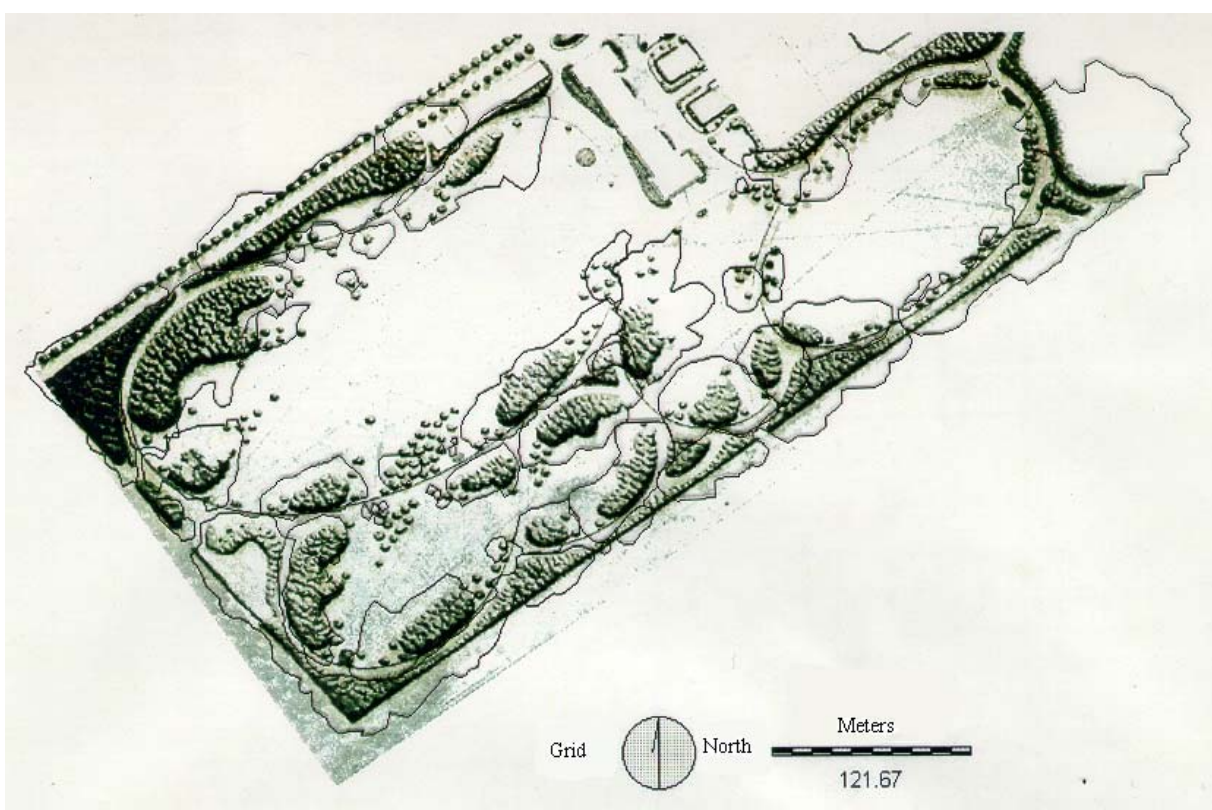

De maneira geral, analisando-se o ano de 1945, tem-se no somatório das áreas dos maciços, $40.576 \mathrm{~m}^{2}$ (ou entorno de 4,06 ha), que representa $27,07 \%$ de cobertura arbórea/arbustiva, em um parque de aproximadamente $150.000 \mathrm{~m}^{2}$ (15 ha), enquanto esse valor, em 1995, sobe para $77.221 \mathrm{~m}^{2}$ (ou 7,72 ha), representando $51,5 \%$ do total do parque. Esses valores são preocupantes do ponto de vista de planejamento paisagístico, pois, considerando-se o projeto original, em que essa cobertura deveria ser mantida em $28.641 \mathrm{~m}^{2}$ (ou próximo de 2,86 ha), representando 19\% do total do parque é, na realidade, até o ano de 1995, o equivalente a mais da metade de sua área total $(51,5 \%)$, tendo $170 \%$ a mais de cobertura arbórea/arbustiva do que o projetado.

Quando se analisam os dados dos maciços ano a ano, observa-se que o crescimento de suas áreas arbóreas não é constante, chegando, muitas vezes, a diminuir de tamanho (Figuras 13 a 18). Isto se deve ao fato de se estar estudando maciços arbóreos no estágio clímax, sendo eles muito dinâmicos, em que se abrem clareiras de tempos em tempos e em lugares distintos dentro dos mesmos. Ao longo dos anos, essas clareiras são cicatrizadas por árvores que crescem nesse espaço, fechando-as - processo da sucessão secundária definida por Kageyama (1986). Este efeito é mais evidenciado quando a clareira é aberta na borda do maciço, interferindo em seu perímetro. Além disso, ainda se computam os erros de medição, comuns em todo o processo.

Quanto à verificação da influência do posicionamento do maciço, com face maior leste e, portanto, recebendo a insolação vespertina ou com face oeste, e, por conseguinte, recebendo insolação matutina, relacionado ao crescimento dos mesmos, o resultado não apontou significância, a 5\% de probabilidade, porém os maciços que receberam a insolação vespertina tiveram 


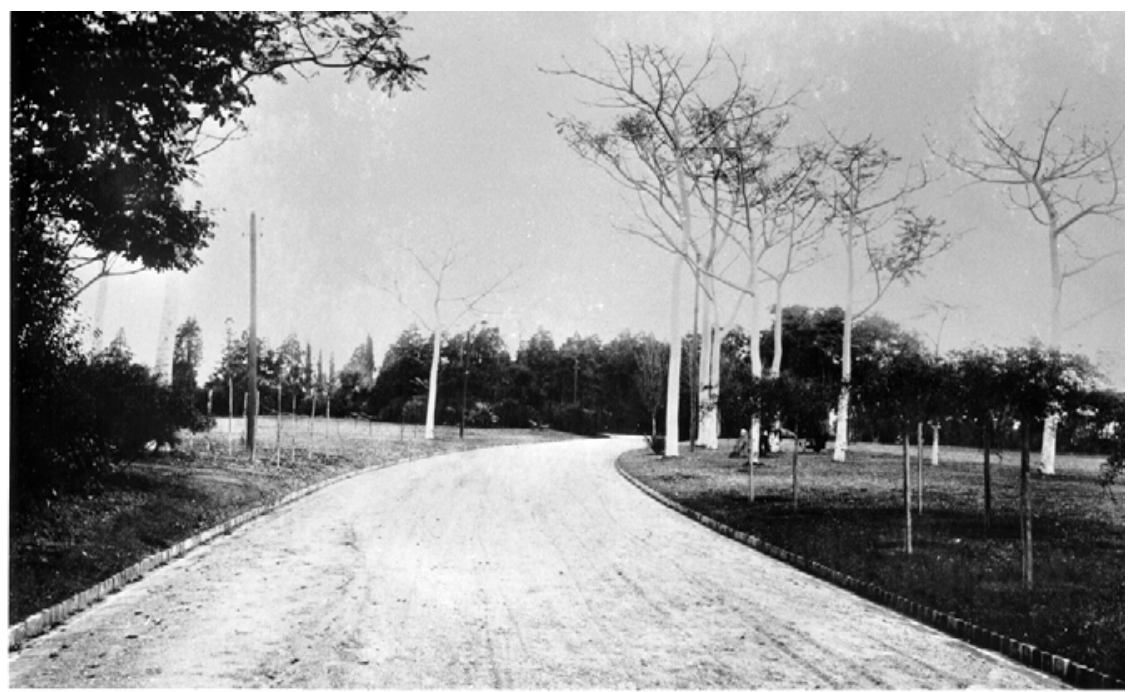

84
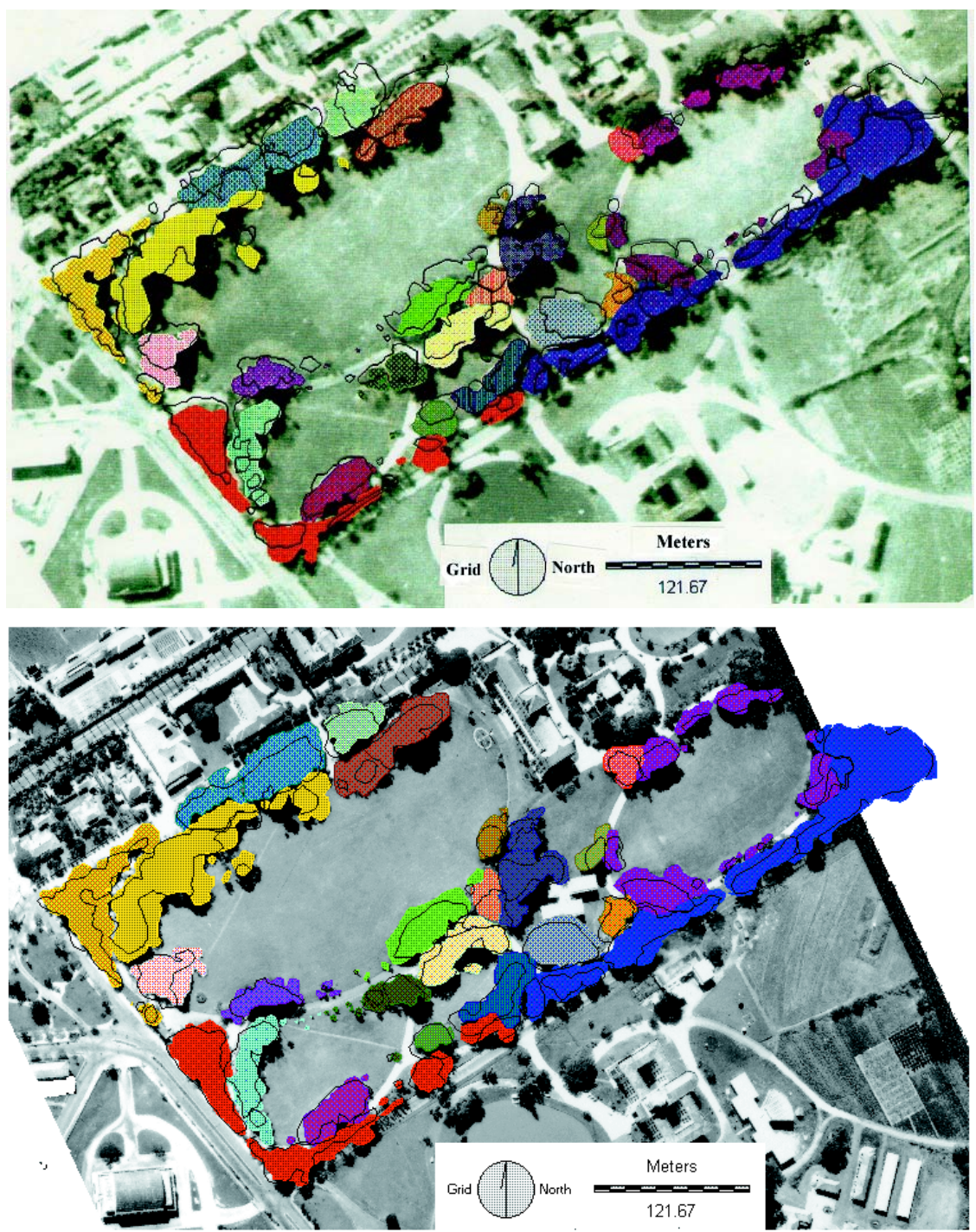

Figura 13 -

Fotografia do

Parque da ESALQ,

mostrando árvores

plantadas com

espaçamento

maior, no intuito de

não-formação de

maciço, conforme

o projeto por

Puttemans

Fonte: Arquivo

ESALQ

Figura $14 a-$

Fotoimagem

ressaltando os

maciços arbóreos

presentes na

fotografia aérea

de 1962

(aéreas coloridas),

sobreposta por

layer elaborado

na digitalização da

fotografia aérea de

1945 (contornos

em preto)

Fonte: Barbin

Figura $14 b-$

Fotoimagem

ressaltando os

maciços arbóreos

presentes na

fotografia aérea

de 1969 (áreas

coloridas),

sobreposto por

layer elaborado na

digitalização da

fotografia aérea

de 1962

(contornos em

preto)

Fonte: Barbin 
Figura 14c-

Fotoimagem

ressaltando os maciços arbóreos

presentes na

fotografia aérea de

1973 (áreas

coloridas)

sobreposta por

layer elaborado na digitalização da

fotografia aérea de

1969 (contornos

em preto)

Fonte: Barbin

Figura 14d -

Fotoimagem

ressaltando os

maciços arbóreos

presentes na

fotografia aérea de

1993 (aéreas

coloridas),

sobreposta por

layer elaborado na

digitalização da

fotografia aérea de

1973 (contornos

em preto)

Fonte: Barbin

Figura 14e-

Fotoimagem

ressaltando os

maciços arbóreos

presentes na

fotografia aérea de

1995 (áreas

coloridas)

sobreposta por

layer elaborado na

digitalização da

fotografia aérea de

1993 (contornos

em preto)

Fonte: Barbin
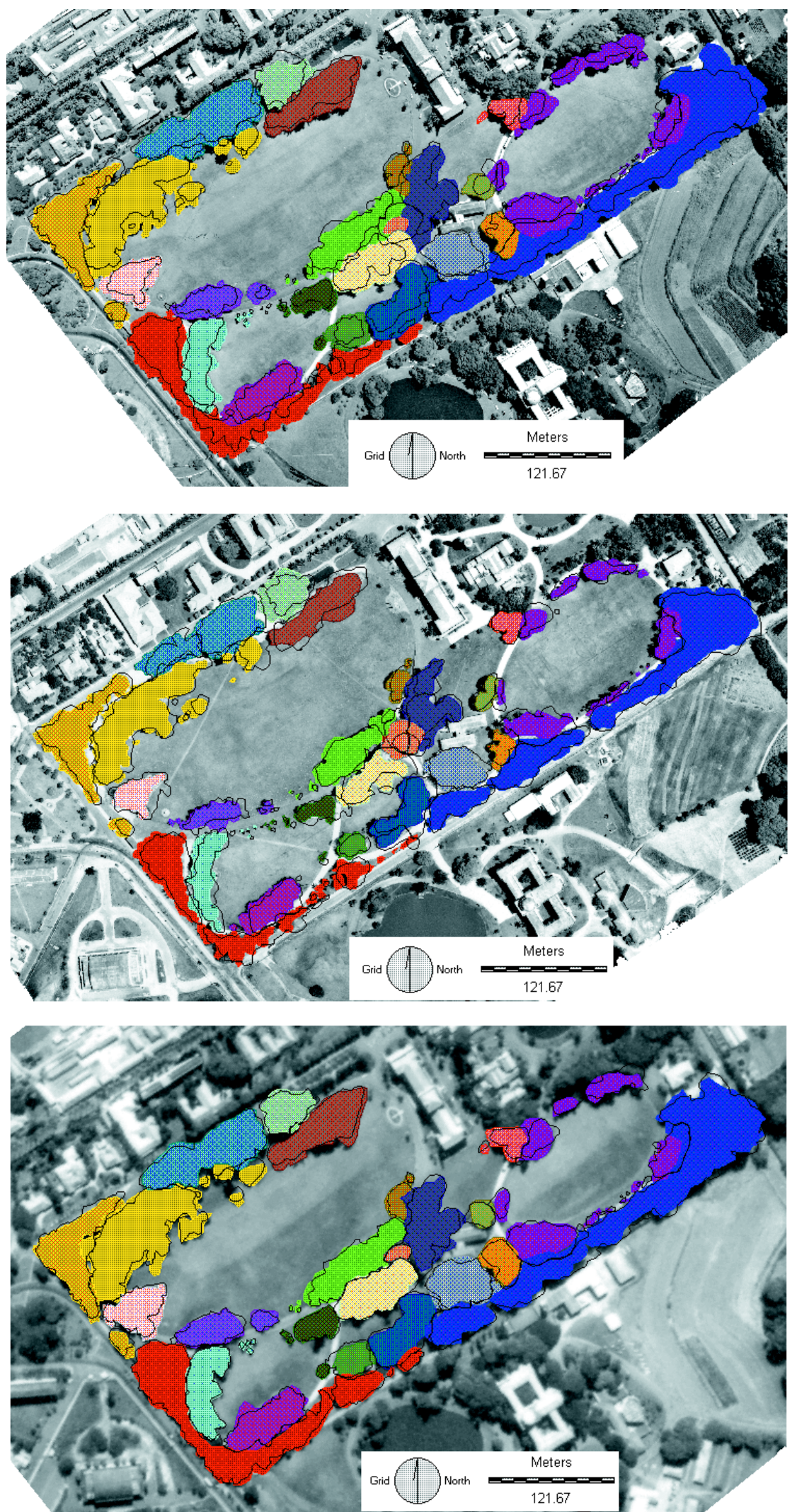


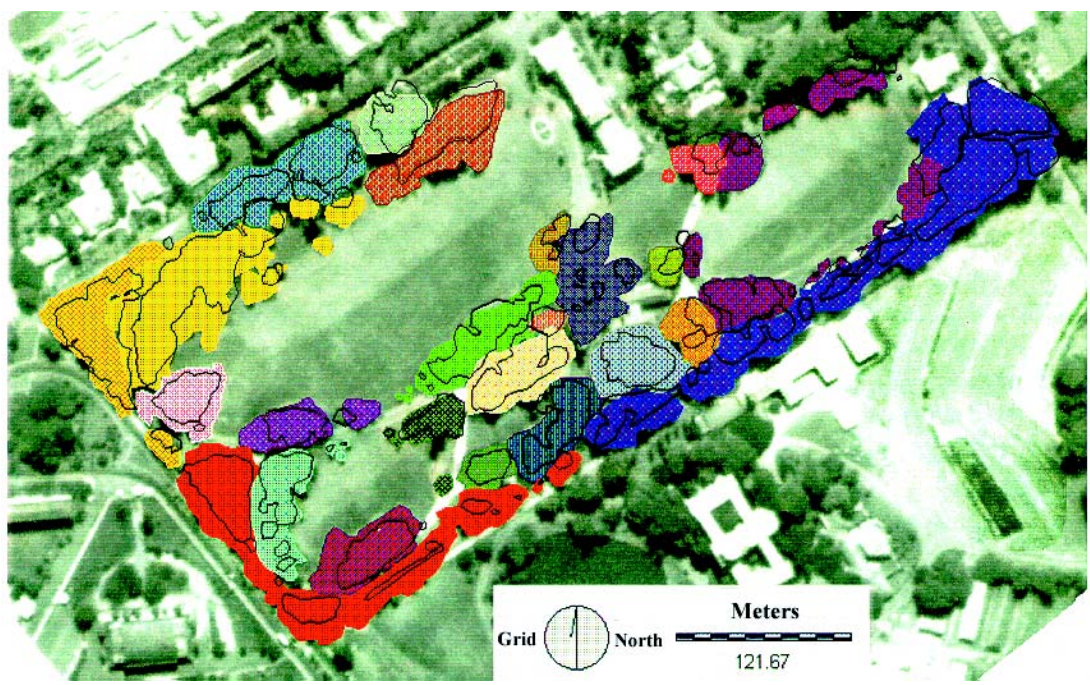

Figura $14 f-$

Fotoimagem ressaltando os maciços arbóreos presentes na fotografia aérea de 1995 (aéreas coloridas), sobreposta por layer elaborado na digitalização da fotografia aérea de 1945

(contornos em preto) sendo, portanto, a maior amplitude, em anos, estudada Fonte: Barbin

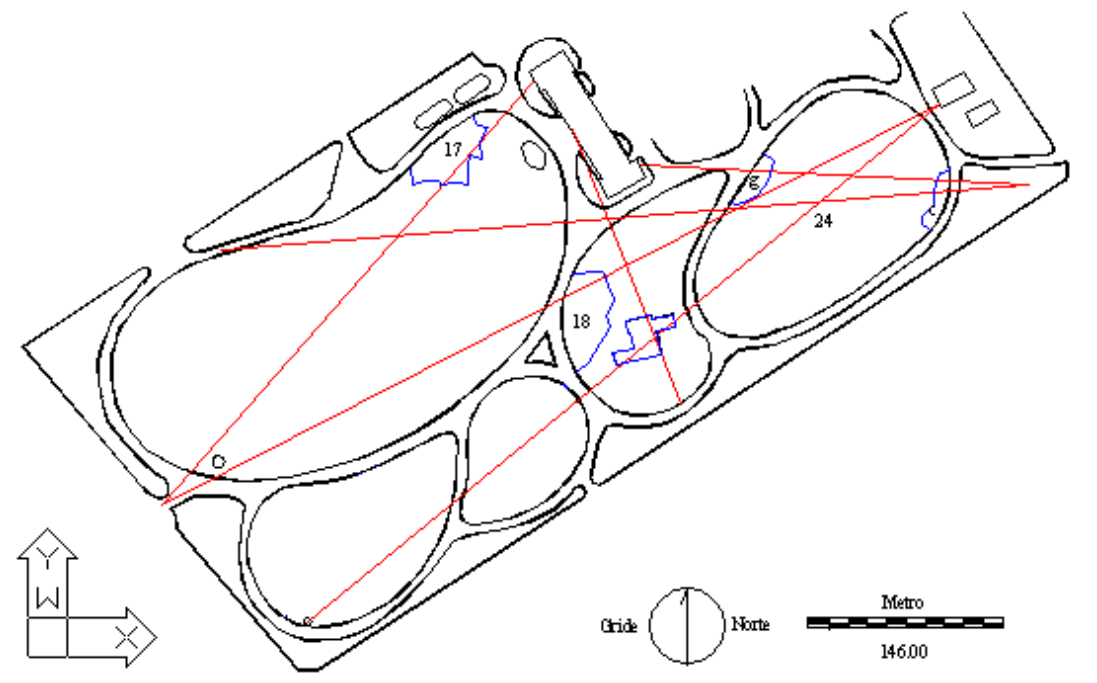

Figura 15 Imagem mostrando as linhas de visada obstruídas (linhas vermelhas), os maciços 17, 18, os minimaciços $24 \mathrm{c} \mathrm{e}$ $24 \mathrm{~g}$ e o Prédio da Seção de Alunos, que interrompem as linhas Fonte: Barbin

maior crescimento. Para os com face leste ou oeste, que recebem insolação direta, no período matutino ou vespertino, confrontados com os de face sul e norte e, logo, não recebem insolação direta em nenhum momento do dia, os resultados também foram não-significativos a $5 \%$ de probabilidade, porém houve maior crescimento dos maciços que receberam insolação direta.

\section{Botânica dos maciços}

Do ponto de vista botânico, nota-se que houve inúmeras mudanças, tanto em quantidade de indivíduos arbóreos quanto em número de espécies presentes nesta parte do parque em estudo. Pode-se notar, no levantamento florístico realizado em 1965, por Fadigas, que a área em estudo era formado por 444 indivíduos arbóreos e, em 1991, pelo novo levantamento (realizado por 
Ricardo R. Rodrigues), passa a ser composto por 2.904 indivíduos, tendo, portanto, seis vezes mais árvores que no primeiro levantamento.

Quanto às espécies vegetais, houve diminuição no número de espécies arbóreas de um levantamento para o outro. Em 1965, a parte do parque estudada era composta por 241 espécies, estando, em 1991, formado por 215 espécies. Esses dados se mostram muito preocupantes, notando-se ainda a presença de reboleiras em alguns maciços, ocorrendo grande domínio de algumas espécies sobre outras. No período estudado, 154 espécies foram extintas da área em estudo, outras 124 foram incorporadas, no mesmo período. Um total de apenas 90 árvores aparecem nos dois levantamentos.

Propõe-se, portanto, um manejo racional nos maciços estudados, para que haja um equilíbrio maior entre as espécies, pela retirada de árvores, de espécies que estão dominando, tais como Johanesia princeps (Boleira), Holocalix balansae (Alecrim-de-Campinas), Anadenanthera sp. (Angico), Myrcia laurotteana (Cambui), Casearina silvestris (Guaçatonga), Allophylus edulis (Chal-chal), Machaerium villosum (Jacarandá-paulista), Aspidosperma ramiflorum (Guatambu), Rhamnidium aleocarpum (Saguaragi), além de várias espécies de palmeiras, dentre elas a Syagrus romanzoffiana (Jerivá) e algumas espécies de pinheiros.

Pelos dados analisados, pode-se verificar que em 24 anos houve mudanças. $\bigcirc$ que poderá ocorrer nos próximos 100 anos, se nenhuma intervenção humana for feita? A biodiversidade está diminuindo e estão criando-se reboleiras de espécies únicas dentro dos maciços. Seria isto interessante? $\bigcirc$ parque é fruto de um reflorestamento e não um remanescente de floresta nativa, mas já possui relações entre espécies diferentes das que ocorrem dentro de um remanescente de mata. Além disso, as técnicas hoje conhecidas de reflorestamento, tais como: os processos sucessionais, agentes dispersores, etc., muito provavelmente não foram previstos na implantação do projeto. Seria de extrema valia, para um estudo como este, se houvesse a relação de plantas utilizadas na época da implantação do projeto, ou ainda, se houvesse levantamentos de todas espécies, tais como os citados neste trabalho, realizado em tempos anteriores.

\section{Descaracterização das Linhas de Visadas Imaginárias}

Conforme comentado, várias características propostas no projeto original do parque foram modificadas, porém, para propor a volta de todas as características planejadas, muito deveria ser feito, inclusive a remoção de um prédio, drástica redução nos maciços, o que seria totalmente inviável. Propõe-se, então, a volta de apenas algumas características viáveis, tais como a desobstrução das linhas de visadas imaginárias.

Das 10 linhas de visada imaginárias propostas pelo paisagista no projeto do parque, podemos observar a existência de seis linhas obstruídas (linhas vermelhas) por maciços e o Prédio da Seção de Alunos (Figura 19) e quatro linhas desobstruídas. 
Esses dados mostram, mais uma vez, a necessidade de realizar-se um manejo mais adequado ao parque, principalmente, nos maciços, que devem, seguindo orientação, terem transplantadas as mudas e, as árvores de grande porte, em estado terminal, serem retiradas e não replantadas no mesmo local. As árvores sem grande expressão e as existentes em grande número devem também ser retiradas. Quanto às linhas de visadas interceptadas pelo Prédio da Seção de Alunos, ficam impossibilitadas suas desobstruções.

Ressalta-se, ainda, a urgência de manejo dos outros maciços existentes no parque, em relação à contenção do crescimento, em área, seja pela proximidade dos mesmos às linhas de visada, caso dos maciços 10, 13, 14 e 21 , seja para conter uma maior descaracterização do parque.

Quanto ao Prédio da Seção de Alunos é lamentável a escolha daquele local para sua construção, no tocante à descaracterização do projeto original, vindo, entre outras coisas, obstruir duas linhas de visada. Portanto, com a prática de manejo dos maciços arbóreos, podem-se recuperar três linhas de visada, ficando uma outra para o futuro, quando as árvores do minimaciço $24 \mathrm{~g}$ perecerem.

\section{Conclusões}

Os maciços do parque da ESALQ poderiam ter sido submetidos à manutenção desde 1927, para manter a conformação, as características e os efeitos propostos pelo paisagista Arsenio Puttemans. Porém, não é o que os dados mostram, pois os mesmos tiveram um crescimento demasiado e desordenado, descaracterizando, assim, a conformação do projeto original. A área de cobertura arbórea/arbustiva, de aproximadamente $30.000 \mathrm{~m}^{2}$, foi em muito superada em 1945 (data da fotografia mais antiga obtida), sendo a mesma de $40.576 \mathrm{~m}^{2}$ e, em 1995 (último vôo), esta medida passa a $77.221 \mathrm{~m}^{2}$. Deve-se, porém, a partir de agora, realizar levantamentos florísticos e fitossociológicos periódicos nos maciços arbóreo/arbustivos, com locação topográfica dos indivíduos, a fim de se observarem se as mudanças propostas surtiram o efeito esperado, além de manter o banco de dados das espécies que compõem os maciços arbóreo/arbustivos atualizados.

Das dez linhas de visadas imaginárias propostas pelo paisagista, no projeto original, seis estão interrompidas, sendo quatro delas, por maciços arbóreo/ arbustivos, e duas, pelo Prédio da Seção de Alunos. Do total interrompido, quatro delas poderão ser desobstruídas, pelas práticas simples de manejo.

Devem-se realizar desbastes de árvores de espécies que estiverem desequilibrando a biodiversidade nos maciços e evitando o plantio de árvores nos locais em que os maciços foram corrigidos. É imprescindível realizar observações periódicas nas linhas de visadas e nos maciços arbóreo/arbustivos do parque, no tocante à área dos mesmos, principalmente em seu perímetro, evitando que eles voltem a crescer. Merecem urgência as revisões dos maciços de números $10,13,14$ e 21 , pois os mesmos já tangenciam algumas linhas de visada. 
No interior dos maciços, devem ser introduzidas árvores de espécies extintas no período estudado, observando a fitossociologia de cada espécie, para auxiliar sua distribuição. Devem ser introduzidas, também, espécies que sejam de interesse para estudos e pesquisas, e ainda, plantas de espécies presentes no parque, representadas por apenas um indivíduo, e que o mesmo esteja danificado, doente, praguejado ou com idade avançada.

Deverão ser implementadas, na administração do campus, leis que orientem a construção de prédios na área do parque.

A introdução de plantas ornamentais de pequeno porte em locais de destaque, tais como: borda de maciços, beira de ruas, etc. e manter as já existentes ao redor do Prédio Central, as quais, conforme os preceitos de Bellair \& Bellair (1939), refletiria no parque ainda mais beleza.

Deverão ser introduzidas novas espécies arbóreas em áreas que ainda estão disponíveis, como, por exemplo, os jardins do Pavilhão de Engenharia, cujos canteiros já estão delimitados.

\section{Bibliografia}

BELLAIR, G. A.; BELLAIR, P. A. Parcs et jardins. Paris: Encyclopédie Agricole, 1939. $348 \mathrm{p}$.

CAMPOS, S. A. Áreas verdes de Piracicaba. Anais da Escola Superior de Agricultura "Luiz de Queiroz", v. 48, p. 71-107, 1991.

KAGEYAMA, P. Y. Estudo para implantação de matas ciliares de proteção na Bacia Hidrográfica do Passa Cinco, visando a utilização para abastecimento público. Piracicaba: FEALQ; DAEE; ESALQ, 1986. 34 p.

LIMA, A. M. L. P. Nosso parque faz 80 anos. Revista da ADEALQ, v. 10, n. 6, p. 2022, 1987.

MONTENEGRO, H. W. S. A arte de projetar jardins. Piracicaba: FEALQ, 1983. $134 \mathrm{p}$.

RANZANI, G. Manual de levantamento dos solos. São Paulo: Edusp, 1965.112 p.

SPURR, S. H. Aerial photographs in forestry. Nova York: The Ronald Press, 1948. $340 \mathrm{p}$.

VASCONCELLOS, P. W. C. de. O marco geográfico da ESALQ. In: ESCOLA SUPERIOR DE AGRICULTURA "LUIZ DE QUEIROZ". ESALQ 75: 75 anos a serviço da Pátria. Piracicaba: FEALQ, 1976. p. 94. 